\title{
Penentuan Validitas Modul Ikatan Kimia Berbasis Inkuiri Terbimbing
}

\author{
S U Sari ${ }^{1}$ and Iryani1 ${ }^{1 *}$ \\ ${ }^{1}$ Pendidikan Kimia, Universitas Negeri Padang, J1. Prof. Dr. Hamka Air Tawar Barat, \\ Padang Utara, Sumatera Barat 25171, Indonesia \\ *iryaniachmad62@gmail.com
}

\begin{abstract}
This research aims to produce a guided-inquiry based module on Chemical Bonding, also to categorize validity of the module. It is a Research and Development which is used Plomp model which consists of three stages, preliminary research, prototyping stage and assessment phase. The instrument used for this research is questionnaire for validation. Was validated by 5 people, 3 lecturers of Chemistry Department FMIPA UNP and 2 chemistry teachers of SMA Pertiwi 1 Padang. The analysis result of validity sheet showed the average Kappa moment $(\mathrm{k})$ was 0.86 . The module that has been produced is very valid to be used.
\end{abstract}

\section{Pendahuluan}

Materi ikatan kimia merupakan salah satu materi yang dipelajari pada semester ganjil kelas X SMA/ MA. Materi ini mencakup dimensi pengetahuan faktual, konseptual, dan prosedural. Materi ikatan kimia merupakan materi pokok yang penting dipahami oleh peserta didik karena materi ini merupakan materi prasyarat dalam mempelajari materi selanjutnya seperti materi bentuk molekul, tata nama, persamaan reaksi, dan sebagainya. Jika peserta didik belum menguasai materi ikatan kimia ini, maka peserta didik akan kesulitan dalam memahami materi selanjutnya. Akan tetapi, materi ikatan kimia dianggap sebagai materi yang sulit dipahami pada kelas $\mathrm{X}$, karena terdapat banyak konsep yang abstrak dan membutuhkan pemahaman konsep yang lain seperti konfigurasi elektron, teori atom, dan lain-lain [1]. Materi tersebut akan lebih mudah dipahami oleh peserta didik serta melekat dalam pikirannya dan tidak menjadi hafalan baginya apabila peserta didik diarahkan untuk memahami konsep dengan cara penemuan konsep sendiri serta menempatkan peserta didik sebagai subjek belajar. Hal ini sesuai dengan tuntutan kurikulum 2013 yang berlaku saat ini.

Kurikulum 2013 revisi 2018 mencanangkan bahwa pembelajaran harus berpusat kepada peserta didik, berpikir kritis, dan aktif dalam mencari atau penemuan konsep [2]. Kurikulum 2013 menuntut guru melaksanakan pembelajaran dengan pendekatan saintifik, pendekatan saintifik dalam pembelajaran perlu diperkuat dengan menerapkan model pembelajaran seperti pembelajaran berbasis penyingkapan/ penelitian (discovery/inquiry learning), pembelajaran berbasis pemecahan masalah (problem based learning) dan pembelajaran berbasis projek (project based learning) [3]. Model-model pembelajaran ini dapat diterapkan dalam suatu bahan ajar, salah satu model pembelajaran yang telah dikembangkan dalam bahan ajar adalan model pembelajaran inkuiri.

Model pembelajaran inkuiri merupakan model pembelajaran yang lebih menekankan kepada proses berfikir kritis serta analitis dalam mencari dan menemukan sendiri jawaban dari suatu masalah yang berorientasi kepada siswa (student centered approach) [4]. Salah satu tingkatan dari model pembelajaran inkuiri yaitu model pembelajaran inkuiri terbimbing. Model pembelajaran inkuiri terbimbing terdiri dari 5 tahapan yaitu orientasi, eksplorasi, pembentukan konsep, aplikasi dan penutup [5]. Salah satu bahan ajar yang telah dikembangkan dengan model pembalajaran inkuiri terbimbing adalah berupa modul berbasis inkuiri terbimbing. Modul berbasis inkuiri terbimbing merupakan modul yang dikembangkan berdasarkan tahapan model pembelajaran inkuiri terbimbing. Modul ini sesuai dengan 
tuntutan pembelajaran pada Kurikulum 2013 revisi 2018 yang menuntut adanya bahan ajar yang mampu melibatkan siswa aktif untuk mencari dan berpikir kritis dalam proses pembelajaran [6]

Penelitian terkait pengembangan bahan ajar berbasis inkuiri terbimbing telah dilakukan oleh Andromeda,dkk (2015) telah menghasilkan bahan ajar yang valid dan praktis digunakan dalam pembelajaran kimia SMA/MA [7]. Penelitian yang telah dilakukan oleh Iryani,dkk (2016) juga dapat disimpulkan bahwa bahan ajar dengan menggunakan model pembelajaran inkuiri terbimbing memberikan pengaruh yang positif terhadap hasil belajar siswa [8]. Penelitian lain yang dilakukan oleh Wafiroh, dkk (2017) dengan judul "Pengembangan Modul Pembelajaran Berbasis Inkuiri Terbimbing untuk Meningkatkan Kemampuan Berpikir Tingkat Tinggi", diperoleh hasil bahwa modul pembelajaran berbasis Inkuiri Terbimbing cukup efektif untuk meningkatkan kemampuan berpikir tingkat tinggi siswa [9].

Penelitian sebelumnya yang terkait dengan pengembangan bahan ajar berbasis inkuiri terbimbing pada materi ikatan kimia telah dilakukan oleh Ariska (2018). Ariska telah menghasilkan modul ikatan kimia berbasis inkuiri terbimbing terintegrasi eksperimen yang valid dan praktis. Pada penelitian ini dikembangkan bahan ajar dengan soal-soal tipe HOTS, adanya soal-soal tersebut ditujukan untuk melatih dan mengembangkan pola berpikir siswa sesuai dengan tuntutan kurikulum 2013 dan juga dilengkapi dengan pendidikan Al- Qur'an dan Budaya Alam Minangkabau sesuai dengan anjuran Dinas Pendidikan Sumatera Barat (2017) sejalan dengan pengembangan kompetensi religius dan sosial ( KI 1 Dan KI 2 ), sebagai penguatan Pendidikan Karakter [10]. Berdasarkan hal tersebut, maka penulis mengembangkan modul ikatan kimia berbasis inkuiri terbimbing dilengkapi soal-soal HOTS pada tahapan aplikasi maupun evaluasi. Disamping itu, disajikan juga beberapa ayat Al- Qur'an serta petatah petitih Minangkabau sesuai dengan materi yang relevan yang terletak dibagian orientasi pada sintaks inkuiri terbimbing pada motivasinya.

Pada penelitian ini dilakukan uji validitas terhadap produk yang dikembangkan berupa modul ikatan kimia berbasis inkuiri terbimbing. Validitas merupakan aspek pertama penentuan kualitas suatu produk. Validitas merupakan penilaian terhadap rancangan suatu produk. Validasi dari suatu produk dapat dilakukan oleh beberapa pakar atau tenaga ahli yang sudah berpengalaman untuk menilai kelemahan dan kekuatan produk yang dihasilkan [11]

Hasil angket yang diberikan kepada siswa dan wawancara dengan guru dibeberapa SMA di Kota Padang (SMAN 10 Padang dan SMA Pertiwi 1 Padang) diperoleh bahwa pembelajaran kimia pada materi Ikatan Kimia pada umumnya menggunakan bahan ajar dalam bentuk buku paket dan LKPD. Dari hasil wawancara dengan guru, bahan ajar yang digunakan belum mampu melatih keterampilan berpikir tingkat tinggi siswa dan juga bahan ajar yang digunakan belum terintegrasi Al-Qur'an dan nilainilai Budaya Alam Minangkabau. Tujuan penelitian ini adalah untuk menghasilkan serta menentukan kategori validitas dari modul yang dikembangkan.

\section{Metode}

Jenis penelitian yang digunakan adalah penelitian dan pengembangan atau Research and Development(R\&D) [11]. Model Pengembangan yang digunakan adalah model plomp dengan 3 tahap pengembangan, yaitu tahap penelitian awal (preliminary research), tahap pembentukan prototipe (prototype stage) dan tahap penilaian (assessment phase) [12]. Subjek penelitian ini adalah 3 dosen kimia FMIPA UNP dan 2 guru kimia SMA Pertiwi 1 Padang. Objek penelitian ini adalah modul ikatan kimia berbasis inkuiri terbimbing.

Pada tahap penelitian tahap awal (preliminary research), dilakukan 4 tahapan yaitu analisis kebutuhan, analisis konteks, studi literatur, dan pengembangan kerangka konseptual. Analisis kebutuhan dilakukan melalui wawancara dengan 2 orang guru kimia SMA di Kota Padang (SMAN 10 Padang dan SMA Pertiwi 1 Padang) serta penyebaran angket kepada 150 siswa SMAN 10 Padang dan 30 siswa SMA Pertiwi 1 Padang berkaitan dengan bahan ajar yang digunakan pada proses pembelajaran dalam materi ikatan kimia. Pada analisis konteks dilakukan analisis terhadap kurikulum dan silabus. Studi literatur dilakukan dengan cara mencari sumber-sumber dan referensi yang relevan yang berkaitan dengan kegiatan penelitian. Pada pengembanagan kerangka konseptual dilakukan dengan cara mengidentifikasi, merinci, dan menyusun konsep-konsep utama yang akan dipelajari pada materi ikatan kimia (analisis konsep) sehingga dihasilkan peta konsep. 
Pada tahap pembentukan prototipe (prototyping stage) dilakukan tiga tahapan yaitu: evaluasi diri sendiri (self evaluation); penilaian ahli (expert review) dan uji satu-satu (one-to-one evaluation); uji coba kelompok kecil (small group evaluation); kemudian pada tahap penilaian (assessment phase) dilakukan uji lapangan (field test) [12]. Prototipe I di evalusi melalui evaluasi diri sendiri (self evaluation) dengan menggunakan sistem check list untuk melihat kelengkapan komponen-komponen penyusun prototipe dan kesalahan dari prototipe. Hasil evaluasi dari prototipe I kemudian direvisi sehingga dihasilkan prototipe II. Prototipe II dilakukan evaluasi formatif berupa uji coba satu satu (one-to-one evaluation) dan penilaian oleh ahli (expert review). Evaluasi ini dilakukan untuk mendapatkan tingkat validitas dari prototipe II. Berdasarkan hasil yang diperoleh dari penilaian ahli dan uji coba satu satu, dilakukan revisi terhadap prototipe II sehingga dihasilkan prototipe III. Pada penelitian ini dibatasi sampai tahap pembentukan prototipe saja yaitu sampai tahap penilaian ahli (validasi).

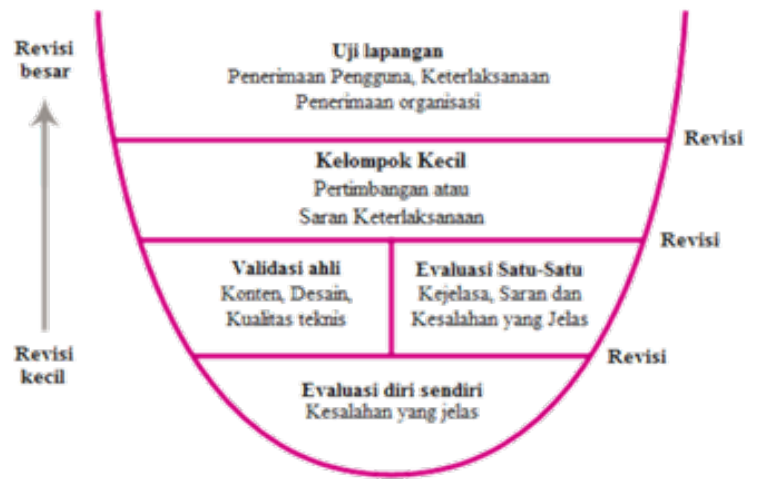

Jenis data yang diperoleh pada penelitian ini adalah data primer yaitu data yang diperoleh secara langsung dari dosen kimia FMIPA UNP dan guru kimia SMA Pertiwi 1 Padang. Instrumen yang digunakan pada penelitian ini adalah angket validasi berupa lembar validasi modul berbasis inkuiri terbimbing digunakan untuk menilai kelayakan isi, kelayakan konstruks (komponen penyajian), komponen kebahasaan, dan komponen kegrafisan dari modul yang dihasilkan [11]. Data yang didapatkan digunakan untuk mengungkapkan tingkat validitas modul yang dirancang yang akan dianalisis dengan menggunakan formula kappa cohen [13].

$$
\text { momen kappa }(K)=\frac{\rho_{o}-\rho_{e}}{1-\rho_{e}}
$$

Keterangan:

$\mathrm{K}$ = momen kappa yang menunjukkan validitas produk

$\rho o=$ Observed Agreement yaitu proporsi yang terealisasi,dihitung dengan cara jumlah nilai yang diberikan validator dibagi jumalah nilai maksimal

$\rho \mathrm{e}=$ Expected Agreement yaitu proporsi yang tidak terealisasi, dihitung dengan cara jumlah nilai maksismal dikurangi dengan jumlah nilai maksimal.

Tabel 1. Kategori Berdasarkan momen Kappa

\begin{tabular}{c|c} 
Interval & Kategori \\
\hline $0.81-1.00$ & Sangat tinggi \\
\hline $0.61-0.80$ & Tinggi \\
\hline $0.41-0.60$ & Sedang \\
\hline $0.21-0.40$ & Rendah \\
\hline $0.01-0.20$ & Sangat rendah \\
\hline$\leq 0,00$ & Tidak valid
\end{tabular}

\section{Hasil dan Diskusi}

Penelitian yang telah dilakukan menghasilkan produk berupa modul Ikatan Kimia berbasis inkuiri terbimbing yang memiliki kevalidan yang sangat tinggi. Penelitian ini menggunakan model pengembangan Plomp yang terdiri dari tiga tahapan dan dibatasi sampai tahap kedua saja, yang hasilnya akan diuraikan sebagai berikut. 


\subsection{Penelitian awal (preliminary research)}

Tahapan penelitian awal (preliminary research) dilakukan untuk menentukan masalah mendasar yang dihadapi di lapangan serta mencari solusi terhadap masalah tersebut. Adapun tahap-tahap yang dilakukan pada tahap penelitian awal ini adalah sebagai berikut.

3.1.1. Analisis kebutuhan. Tahap analisis kebutuhan telah dilakukan melalui wawancara dengan 2 orang guru kimia SMA di Kota Padang (SMAN 10 Padang dan SMA Pertiwi 1 Padang) dan penyebaran angket kepada 150 siswa SMAN 10 Padang dan 30 siswa SMA Pertiwi 1 Padang. Kegiatan yang dilakukan difokuskan pada permasalah yang terjadi dalam proses pembelajaran pada materi ikatan kimia terutama berkaitan dengan bahan ajar yang digunakan. Hasil analisis kebutuhan melalui wawancara dengan guru dan angket yang diberikan kepada siswa diperoleh hasil bahwa bahan ajar yang digunakan dalam proses pembelajaran pada materi ikatan kimia yaitu berupa buku paket dan LKPD. Bahan ajar tersebut belum menerapkan model pembelajaran tertentu yang berbasis pendekatan saintifik sesuai dengan tuntutan Kurikulum 2013. Kurikulum 2013 menuntut proses pembelajaran dilaksanakan dengan menggunakan pendekatan saintifik. Pembelajaran dengan pendekatan saintifik dapat terwujud dengan menerapkan model pembelajaran, salah satu model pembelajaran yang dapat diterapkan yaitu model pembelajaran inkuiri terbimbing. Hal ini sejalan dengan pendapat yang dikemukakan Sanjaya [4], model pembelajaran inkuiri merupakan suatu rangkaian kegiatan pembelajaran yang menekankan pada proses berpikir kritis serta analitis untuk mencari dan menemukan sendiri jawaban dari suatu masalah yang berorientasi kepada siswa. Hasil wawancara juga menunjukkan bahwa bahan ajar yang digunakan belum dilengkapi soal-soal tipe HOTS, adanya soal-soal tersebut ditujukan untuk melatih dan mengembangkan pola berpikir siswa sesuai dengan tuntutan kurikulum 2013 dan juga bahan ajar yang digunakan belum terintegrasi pendidikan Al-Qur'an dan nilai-nilai Budaya Alam Minangkabau sesuai dengan anjuran Dinas Pendidikan Sumatera Barat (2017) sejalan dengan pengembangan kompetensi religius dan sosial ( KI 1 Dan KI 2 ), sebagai penguatan Pendidikan Karakter.

3.1.2. Analisis konteks. Analisis konteks yang telah dilakukan meliputi analisis terhadap kurikulum dan analisis silabus. Berdasarkan analisis kurikulum, diperoleh hasil bahwa Kurikulum 2013 revisi 2018 mencanangkan bahwa pembelajaran harus berpusat kepada peserta didik, berpikir kritis dan aktif dalam mencari atau penemuan konsep. Analisis terhadap silabus pada Kurikulum 2013 yang telah dilakukan berupa analisis kompetensi dasar yang dijabarkan menjadi indikator pencapaian kompetensi kemudian dirumuskan menjadi tujuan pembelajaran. Kompetensi dasar (KD) dari materi ikatan kimia adalah KD 3.5 membandingkan ikatan ion, ikatan kovalen, ikatan kovalen koordinasi dan ikatan logam serta kaitannya dengan sifat zat dan KD 4.5 merancang dan melakukan percobaan untuk menunjukkan karakteristik senyawa ion atau senyawa kovalen berdasarkan beberapa sifat fisika. Adapun indikator pencapaian kompetensi yang dirumuskan dari KD 3.5 adalah 3.5.1 Menentukan cara suatu atom mencapai kestabilan, 3.5.2 Menganalisis proses terbentuknya ikatan ion, 3.5.3 Menganalisis proses terbentuknya ikatan kovalen, 3.5.4 Menganalisis proses terbentuknya ikatan kovalen tunggal dan ikatan kovalen rangkap, 3.5.5 Menganalisis proses terbentuknya ikatan kovalen koordinasi, 3.5.6 Mendiskusikan adanya senyawa yang tidak memenuhi aturan oktet, 3.5.7 Menganalisis kepolaran senyawa kovalen, 3.5.8 Menganalisis proses terbentuknya ikatan logam, 3.5.9 Mengemukakan sifatsifat ikatan logam. Adapun indicator pencapaian kompetensi yang dirumuskan dari KD 4.5 adalah 4.5.1 Melakukan percobaan untuk membedakan sifat senyawa ion dan senyawa kovalen dan 4.5.2 Melakukan percobaan kepolaran senyawa.

3.1.3. Studi Literatur. Studi literatur yang telah dilakukan diperoleh dari berbagai sumber seperti buku, jurnal, dan sumber lainnya. Adapun komponen modul yang digunakan sebagai acuan dalam penelitian ini dirujuk dari buku Suryosubroto (1983) [14] yaitu petunjuk penggunaan modul, rumusan tujuan pembelajaran yang spesifik, Lembaran kegiatan, Lembaran kerja, Kunci lembaran kerja, lembaran evaluasi dan kunci lembaran evaluasi. Adapun konten atau isi materi dalam produk yang dikembangkan dirujuk dari buku-buku perguruan tinggi seperti model-model pada tahap eksplorasi dan pembentukan konsep (ikatan ion gambarnya dirujuk dari buku Brady, gambar ikatan kovalen dirujuk dari buku brady, Raymond chang, dll), tahapan model pembelajaran inkuiri terbimbing dirujuk dari buku Hanson untuk 
aktivitas kelas (orientasi, eksplorasi, pembentukan konsep, aplikasi dan penutup) dan buku College Board untuk aktivitas labor (eksplorasi, pembentukan konsep dan aplikasi).

3.1.4. Pengembangan Kerangka Konseptual. Berdasarkan analisis konsep yang telah dilakukan, diperoleh hasil bahwa konsep-konsep utama yang harus dikuasai siswa antara lain: ikatan ion, senyawa ion, ikatan kovalen, ikatan kovalen tunggal, ikatan kovalen rangkap dua, ikatan kovalen rangkap tiga, ikatan kovalen koordinasi, ikatan kovalen polar, ikatan kovalen non polar dan ikatan logam.

\subsection{Tahap pembentukan prototype (prototype stage)}

3.2.1. Evaluasi diri sendiri (self evaluation). Evaluasi formatif ini dilakukan dengan tujuan untuk meningkatkan dan menyempurnakan produk. Produk berupa modul yang dikembangkan memiliki komponen modul sesuai dengan komponen modul Suryosubroto [14] yaitu petunjuk penggunaan modul, tujuan pembelajaran, lembaran kegiatan, lembaran kerja, lembaran evaluasi, kunci lembaran kerja, dan kunci lembaran evaluasi dan juga penambahan komponen modul seperti cover, kata pengantar, daftar isi, daftar gambar, daftar tabel, peta konsep, kompetensi inti, kompetensi dasar, indikator pencapaian kompetensi, dan kepustakaan. Penambahan ini bertujuan untuk menyempurnakan produk dan memudahkan dalam penggunaan produk. Prototipe I yang dihasilkan telah dilakukan evaluasi diri sendiri yang diperoleh hasil bahwa prototipe I membutuhkan revisi pada beberapa bagian atau komponen modul yang seharusnya ada pada prototipe I yang dihasilkan yaitu penambahan lembaran evaluasi dan kunci jawaban lembaran evaluasi yang sebelumnya tidak ada menjadi ada. Cover dan revisi (lembaran evaluasi dan kunci lembaran evaluasi) dapat dilihat pada Gambar 1-3.

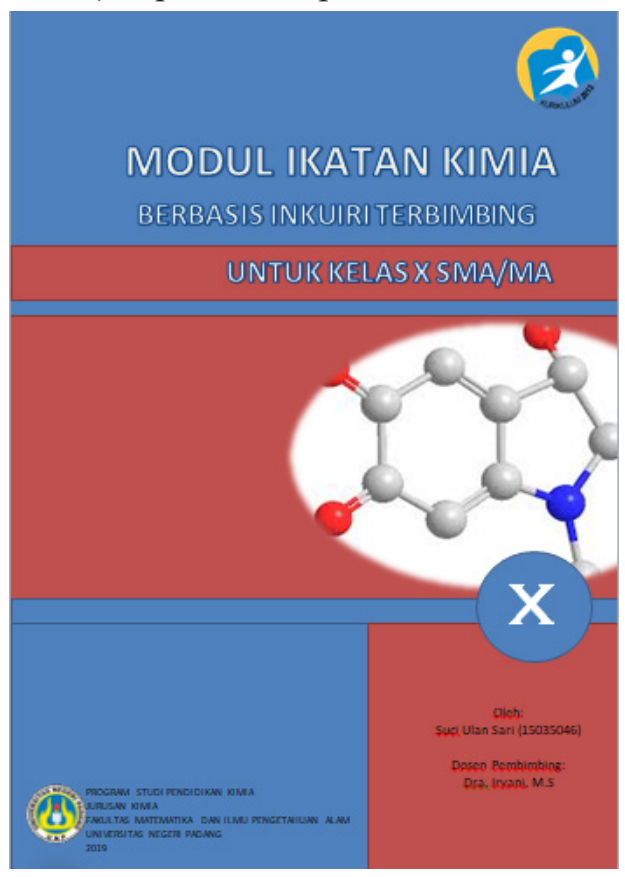

Gambar 1. Cover Modul 


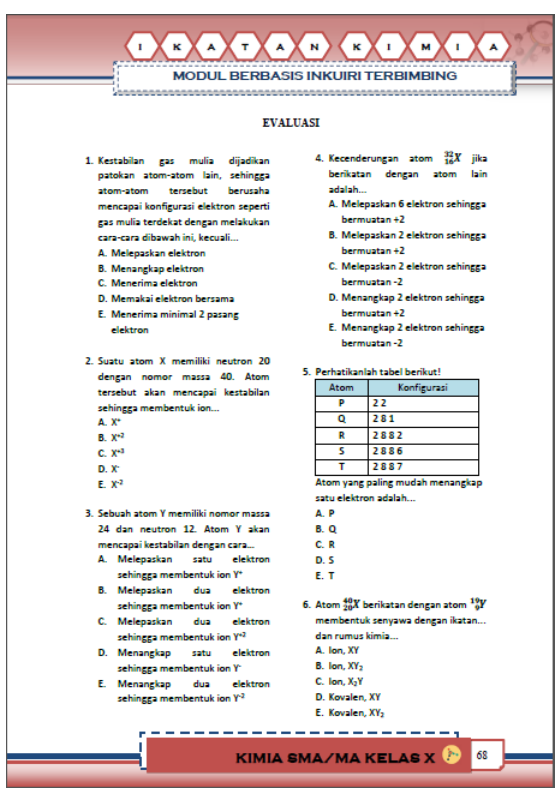

Gambar 2. Lembaran Evaluasi

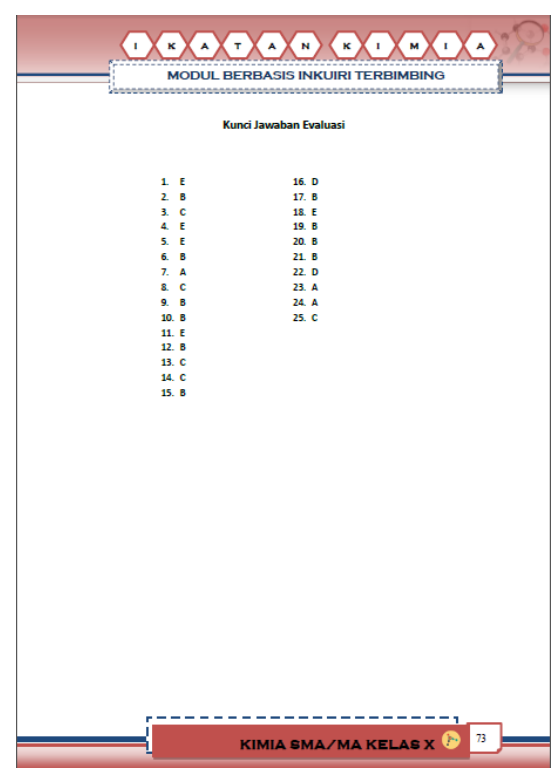

Gambar 3. Kunci Lembaran Evaluasi

3.2.2. Uji coba satu-satu (one-to-one evaluation) dan penilaian ahli (expert review). Pada uji coba satu-satu diperoleh hasil dari segi tampilan berupa cover dan pemilihan warna pada modul dinilai bagus dan juga mampu menarik minat siswa untuk membacanya. Pemilihan jenis dan ukuran huruf pada modul jelas serta bahasa yang digunakan mudah dipahami oleh siswa. Prototipe II yang berupa modul berbasis inkuiri terbimbing dinilai memiliki tahapan pembelajaran yang jelas dan mudah dipahami. Model yang disajikan pada modul dinilai mampu membantu siswa dalam menemukan konsep yang dibantu dengan pertanyaan kunci. Secara umum, modul berbasis inkuiri terbimbing sebagai prototipe II yang telah dihasilkan mampu menuntun siswa dalam menemukan konsep sesuai dengan tujuan dikembangkannya modul berbasis inkuiri terbimbing ini.

Prototipe II yang telah dihasilkan dilakukan penilaian ahli (expert revies) yaitu validasi oleh 5 validator yang terdiri dari 3 dosen Kimia FMIPA UNP dan 2 guru kimia SMA Pertiwi 1 Padang. Validitas modul ditentukan dengan menggunakan lembar angket validasi oleh 5 validator yaitu 3 dosen kimia FMIPA UNP dan 2 guru kimia SMA Pertiwi 1 Padang. Penilaian yang diberikan oleh validator terhadap modul berbasis inkuiri terbimbing meliputi segi kelayakan isi, kelayakan konstruk (komponen penyajian), komponen kebahasaan, dan komponen kegrafisan. Data yang diperoleh diolah dengan menggunakan formula Kappa Cohen. Hasil analisis data validasi modul terhadap semua aspek dapat dilihat pada Gambar 4 berikut.

\section{Hasil Uji Validitas Modul Inkuiri Terbimbing oleh Validator}

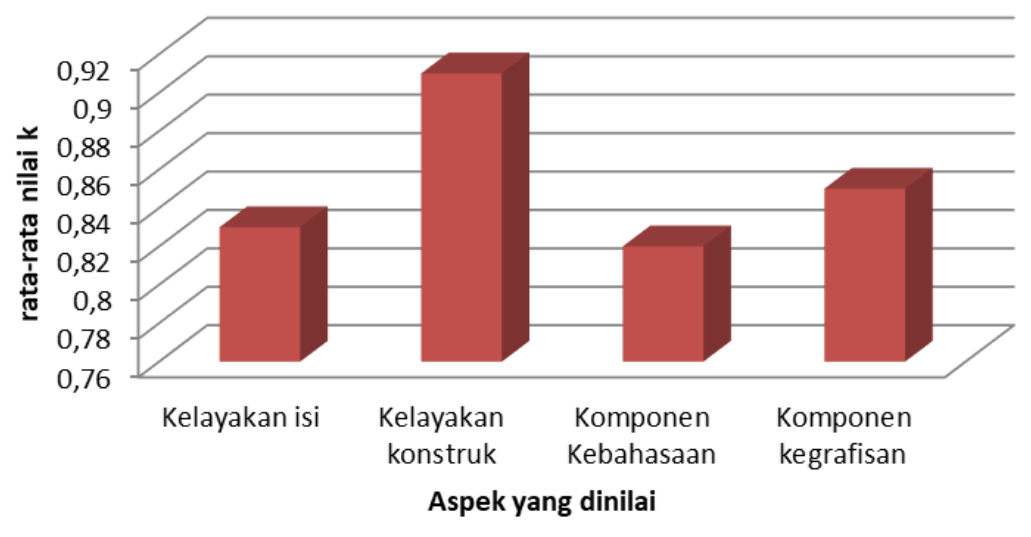

Gambar 4. Hasil analisis data validitas oleh validator 
Penilaian kelayakan isi adalah penilaian terhadap produk yang dikembangkan berdasarkan kurikulum yang relevan dan juga rasional teoritik yang kuat. Berdasarkan hasil analisis data pada Gambar 4 menunjukkan dari segi kelayakan isi, modul ikatan kimia ini mendapatkan nilai momen kappa sebesar 0,83 yaitu kevalidan yang sangat tinggi. Data ini menunjukkan bahwa produk berupa modul ikatan kimia berbasis inkuiri terbimbing untuk melatih keterampilan berpikir tingkat tinggi siswa telah sesuai dengan kurikulum yang digunakan dan dikembangkan dengan kajian teoritik yang kuat. Kesesuaian dari segi kelayakan isi dapat dilihat berdasarkan materi prasyarat, model, pertanyaan kunci serta latihan telah sesuai dengan model pembelajaran yang digunakan yaitu model inkuiri terbimbing. Isi modul yang dikembangkan juga telah sesuai dengan tujuannya yaitu untuk melatih keterampilan berpikir tingkat tinggi siswa yang terintegrasi langsung pada model pembelajaran inkuiri terbimbing.

Penilaian kelayakan konstruk (komponen penyajian) adalah penilaian yang dilakukan menunjukkan konsistensi internal antar komponen yang terdapat pada produk. Berdasarkan hasil analisis data pada Gambar 4 menunjukkan dari segi kelayakan konstruk, modul ini mendapatkan nilai momen kappa sebesar 0,91 yaitu kevalidan yang sangat tinggi. Data ini menunjukkan bahwa produk yang dikembangkan berupa modul berbasis inkuiri terbimbing yang dikembangkan sudah disusun secara sistematis. Penyajian modul ini dinilai sistematis dilihat dari segi penyajian komponen modul, penyajian tahapan pembelajaran, dan penyajian pertanyaan kunci. Penyajian modul dinilai sudah sistematis sesuai dengan komponen modul Suryosubroto [13] yang digunakan sebagai acuan. Modul yang terdiri atas aktivitas kelas dan aktivitas laboratorium dinilai sudah sistematis dan sesuai dengan silkus pembelajaran inkuiri terbimbing. Penyajian pertanyaan kunci sudah sistematis yang dimulai dari pertanyaan faktual dengan kognitif tingkat rendah sampai pertanyaan kognitif tingkat tinggi. Pertanyaan kunci merupakan jantung dari inkuri terbimbing untuk membimbing peserta didik dalam menemukan konsep berdasarkan kegiatan eksplorasi pada model yang disajikan [5].

Penilaian komponen kebahasaan dan komponen kegrafisan didapatkan hasil analisis data pada gambar 4 menunjukkan dari segi komponen kebahasaan dan komponen kegrafisan, modul mendapatkan nilai moment kappa berturut-turut sebersar 0,82 dan 0,85 yaitu kevalidan sangat tinggi. Data ini menunjukkan bahwa produk yang dikembangkan telah menggunakan bahasa yang sesuai dengan kaidah Bahasa Indonesia yang baik dan benar sehingga petunjuk, informasi serta pertanyaan kunci yang ada pada modul jelas dan mudah dipahami. Tata letak (lay out), jenis dan ukuran huruf, dan pemilihan warna dinilai jelas dan menarik secara keseluruhan. Dari keempat aspek penilaian tersebut didapatkan ratarata nilai momen kappa sebesar 0,86 artinya produk yang dihasilkan memiliki kategori kevalidan yang sangat tinggi.

\section{Simpulan}

Berdasarkan penelitian yang telah dilakukan maka dapat disimpulkan bahwa Modul Ikatan Kimia berbasis Inkuiri Terbimbing dilengkapi soal-soal tipe HOTS, pendidikan Al-Qur'an dan Budaya Alam Minangkabau memiliki kevalidan yang sangat tinggi sebesar 0,86 .

\section{Referensi}

[1] Sunyono. L. Yuanita dan M. Ibrahim. 2015. Supporting Students in Learning with Multiple Representation to Improve Student Mental Models on Atomic Structure Concepts. Science Education International Vol. 26, Issue 2, 2015, 104-125

[2] Peraturan Menteri Pendidikan Dan Kebudayaan Republik Indonesia Nomor 36 Tahun 2018 Tentang Perubahan Atas Peraturan Menteri Pendidikan Dan Kebudayaan Nomor 59 Tahun 2014 Tentang Kurikulum 2013 Sekolah Menengah Atas/Madrasah Aliyah

[3] Peraturan Menteri Pendidikan Dan Kebudayaan Nomor 22 Tahun 2016 Tentang Standar Proses Pendidikan Dasar Dan Menengah

[4] Sanjaya, Wina. 2006. Strategi Pembelajaran Berorientasi Standar Proses Pendidikan. Jakarta: Kencana Prenada Media Group

[5] Hanson, David. M. (2005). Designing Process-Oriented Guided-Inquiry Activities. In Faculty Guidedbook: A Comprehensive Tool For Improving Faculty Performance, ed. S. W. Beyerlein and D. K. Apple. Lisle, IL: Pacific Crest. 
[6] Andromeda, Iryani, Mawardi dan Shavira Meidina Irham. 2015. "Pengembangan Bahan Ajar Hidrolisis Garam Berbasis Guided-Inquiry Dengan Representasi Chemistry-Triangle Untuk Siswa SMA/MA." Prosiding SEMIRATA 2015 bidang MIPA BKS-PTN Barat Universitas Tanjungpura, Pontianak Hal. 356 - 365

[7] Iryani, Mawardi, dan Andromeda. 2016. "Pengaruh Penggunaan Lks Berbasis Inkuiri Terbimbing Terhadap Hasil Belajar Siswa Untuk Materi Koloid Kelas XI SMAN 1 Batusangkar.” Jurnal Eksakta Vol. 1 Tahun XVII Februari 2016

[8] Liliasari. 2001. "Model Pengembangan IPA untuk Meningkatkan Keterampilan Berpikir Tingkat Tinggi Calon Guru sebagai Kecenderungan Baru pada Era Globalisasi.” Jurnal Pengajaran MIPA UPI (Vol. 2 No.1)

[9] Wafiroh, Masrurotul Jeffry Handhika dan Erawan Kurniadi. 2017. Pengembangan Modul Pembelajaran Berbasis Inkuiri Terbimbing untuk Meningkatkan Kemampuan Berpikir Tingkat Tinggi. SemNas Pendidikan Fisika III 2017. ISSN : 2527-6670

[10] Dinas Pendidikan Sumatera Barat. 2017. Pengintegrasian Pendidikan Al Qur'an Dan Budaya Alam Minang Kabau Pada Mata Pelajaran Kimia Sekolah Menengah Atas (SMA). Padang: Dinas Pendidikan Provinsi Sumatera Barat.

[11] Sugiyono. 2017. Metode Penelitian Pendidikan. Bandung: Alfabeta.

[12] Plomp, Tjeerd. 2007. "Educational Design Research: An Introduction", dalam An Introduction to Educational Research. Enschede, Netherland: NationalInstitute for Curriculum Development.

[13] Boslaugh, Sarah dan Paul A. W. (2008). Statistics in a Nutshell, a desktop quick reference. Beijing, Cambridge, Famham, Köln, Sebastopol, Taipei,Tokyo: O'reilly.

[14] Suryosubroto, B. 1993. Sistem Pengajaran dengan Modul. Yogyakarta: Bina Aksara. 